\title{
Sun exposure, skin lesions and vitamin D production: evaluation in a population of fishermen*
}

\author{
Roberta Cavalcanti Soriano Coutinho ${ }^{1,2}$, Aldenir Feitosa dos Santos ${ }^{2,3,4}$, João Gomes da Costa ${ }^{3,5}$, \\ Aleska Dias Vanderlei ${ }^{2,6}$
}

DOI: http:/ / dx.doi.org/10.1590/abd1806-4841.20197201

\begin{abstract}
BACKGROUND: Exposure to UVR provides benefits related to vitamin D synthesis, but also causes harms, since UVB is considered a complete carcinogen. There is no definition of the level of sun exposure and the proportion of exposed body required for proper synthesis of vitamin $\mathrm{D}$ in the skin without causing it damage.

ОвлестіVEs: This study aims to analyze the sun exposure index, vitamin D levels and clinical changes in the skin caused by constant sun exposure in the fishermen population.

Methods: It is a cross-sectional, observational and analytical study. The sample consisted of fishermen and was calculated in 174 individuals. The questionnaire was applied, the dermatological examination was carried out and the examinations of calcidiol, parathyroid hormone, calcium and phosphorus were requested. Data were expressed as percentages. The comparative analysis was done through the Chi-square test, and the correlations were established through the Pearson's linear coefficient. RESULTS: We observed that there was vitamin D deficiency in a small part of the cases $(11.46 \%)$, and the frequency of diagnosis of skin cancer was $2.7 \%$ of the cases surveyed.

Study LimitaTions: The difficulty in categorizing the sun exposure index.

CONCLUSION: The fact that fishermen expose themselves to the sun chronically and have been exposed to the sun for more than 15 years, between 21 and 28 hours a week, and without photoprotection, were indicative factors for protection against vitamin D deficiency. Chronic exposure to sun and high vitamin levels D may be indicative of protection of this population against skin cancer.
\end{abstract}

Keywords: Skin neoplasms; Ultraviolet rays; Vitamin D

\section{INTRODUCTION}

The energy emitted by the sun is transmitted as electromagnetic waves that are classified according to their length or frequency of propagation. They are mainly composed by infrared, visible and ultraviolet radiations. This group of radiations is known as optical radiation. Ultraviolet radiation (UVR), how the interval of the electromagnetic spectrum between the wavelengths of $100 \mathrm{~nm}$ and
$400 \mathrm{~nm}$ is known, is subdivided into ultraviolet C (UVC), between $100 \mathrm{~nm}$ and 280nm; ultraviolet $B$ (UVB), between 280nm and 315nm; and ultraviolet A (UVA), between $315 \mathrm{~nm}$ and $400 \mathrm{~nm}^{1}{ }^{1}$

The ultraviolet index (UVI) is a value scale related to the biologically active UVR flow, which induces the formation of erythema in human skin and aims to inform the population about UVR

Received on 12 April 2017

Accepted on 07 January 2018.

* Work conducted at the Centro Universitário CESMAC, Maceió (AL), Brazil.

Financial support: None.

Conflict of interest: None.

Discipline of Dermatology, Centro Universitário CESMAC, Maceió (AL), Brazil.

Program of Post-Graduation, Professional Master's Degree in Health Research, Centro Universitário CESMAC, Maceió (AL), Brazil.

Program of Post-Graduation, Professional Master's Degree in Analysis of Environmental Systems, Centro Universitário CESMAC, Maceió (AL), Brazil.

Discipline de Biochemistry, Universidade Estadual de Alagoas, Arapiraca (AL), Brazil.

Program of Post-Graduation in Agriculture and Environment, Universidade Federal de Alagoas, Maceió (AL), Brazil.

Discipline of Dentistry, Centro Universitário CESMAC, Maceió (AL), Brazil.

MaILING AdDREss:

Roberta Cavalcanti Soriano Coutinho

E-mail: roberta.coutinhos@gmail.com

C2019 by Anais Brasileiros de Dermatologia 
intensity. Based on this parameter, education about the appropriate use of some protection is possible. ${ }^{2}$

Exposure to UVR has psychological and physical benefits, particularly related to the synthesis of vitamin $\mathrm{D}(\mathrm{VD})$ and the prevention of conditions such as osteoporosis, type I diabetes, some types of cancer and autoimmune and cardiovascular diseases. ${ }^{3,4}$

When a UVB light photon reaches the skin, it photoisomerizes 7-dehydrocholesterol (7-DHC) to form pre-cholecalciferol (pre-vitamin D3), which is isomerized into cholecalciferol (vitamin D3). It is then transported to the liver and kidneys where it undergoes hydroxylation and is converted into calcidiol $(25(\mathrm{OH})$ D) and, subsequently, into calcitriol $(1.25(\mathrm{OH}) \mathrm{D})$. This is the most active metabolite, responsible to stimulate calcium and phosphate absorption through the intestines. Hydroxylation in the kidneys is stimulated by the parathyroid hormone (PTH) and suppressed by phosphorus. ${ }^{5,6}$

The dosage of VD is estimated through $25(\mathrm{OH}) \mathrm{D}$, since this is the main circulating form, with a half-life of about 2 to 3 weeks. Its concentration in the serum has a close correlation with the findings of osteomalacia and rickets and with the cutaneous production or ingestion of VD, which accurately reflects the body's supply of this vitamin. Alternatively, the levels of VD can be established through the levels of PTH. Therefore, low values of VD are related to increased levels of PTH which characterizes abnormal calcium homeostasis and secondary hyperparathyroidism. ${ }^{7}$

Hypovitaminosis D occurs when serum concentrations of calcidiol $25(\mathrm{OH}) \mathrm{D}$ are below 30ng/mL (75nmol/L). Serum concentrations below 20ng/ $\mathrm{mL}(50 \mathrm{nmol} / \mathrm{L})$ are classified as VD deficiency; between 20 and $29 \mathrm{ng} / \mathrm{mL}$ (50 and $74 \mathrm{nmol} / \mathrm{L}$ ), as insufficiency and between 30 and $100 \mathrm{ng} / \mathrm{mL}$ (75 e $250 \mathrm{nmol} / \mathrm{L})$, as sufficiency. ${ }^{8}$

At the same time that it is beneficial to human health, solar exposure can also cause damage. UVB is the most damaging wavelength for keratinocyte DNA and is considered a complete carcinogen. This radiation is responsible for the sunburn response and photo carcinogenesis, which consists in the development of skin cancers induced by UVR. Most of these damages are caused by direct and indirect photosensitive reactions and induce DNA breakage and base damage, therefore being lethal and mutagenic.9,10

Because the skin is the most accessible human organ to sunlight, it suffers directly the undesirable effects caused by UVR which nowadays represents the main environmental risk factor for the development of actinic keratosis (AK), squamous cell carcinoma (SCC) and basal cell carcinoma (BCC). ${ }^{11,12}$

The influence of UVR depends on the skin color, which can be evaluated using the classification of Fitzpatrick. This classification determines the different phototypes according to the cutaneous reaction to sun exposure. ${ }^{13}$

Public health campaigns have been developed to improve the knowledge of the general population on the role of this radiation in the development of skin cancer; however, the positive effects mediated by UVB light as the activator of VD production were not properly considered in most of these campaigns. ${ }^{14}$

There is no definition of the level of sun exposure and proportion of exposed body needed for an adequate synthesis of VD in the skin without damaging it. These aspects are important for thorough characterization of this epidemiological situation and are important tools in the education, if needed, of when and how to intervene in the prevention of cancer and vitamin D deficiency. ${ }^{15}$

The municipality studied is situated by the Atlantic Ocean. In its territory there are three rivers, a large number of creeks and watercourses, mangrove forests, besides seven lagoons, being an ecosystem rich in fishes, crustaceans and shellfish. ${ }^{16}$ Due to these characteristics, its economic background is fishing, agriculture, and, lately, tourism. The city has a fishermen colony established in April 1975 that nowadays houses 315 fishermen registered with the Registro Geral de Pesca.

The mean workload in Brazil is 39.4 hours per week. It is estimated that people working outdoors such as fishermen can receive a dose of UV radiation of 6 to 8 times higher than people working indoors, what certainly puts them at risk for the development of skin cancer and raises the interest in assessing their level of VD. ${ }^{17}$

In this context we observe the importance of analyzing the index of solar exposure, the levels of vitamin D and the clinical changes on the skin caused by constant solar exposure in the fishermen population of the municipality.

\section{METHODS}

It is a cross-sectional, observational and analytic study. It was approved by the ethics committee under the number 1.606.041. The sample was made by fishermen of the fishing colony of a city in the northeastern coast. According to the fishermen colony, there are 315 registered fishermen with the Registro Geral de Pesca (RGP) living in the study area. The sample was calculated in 174 individuals with the program OpenEpi ${ }^{\circledR}$, available online, considering an anticipated frequency of $50 \%$ and the accuracy confidence interval of $95 \%$. The selection was random using the registration number through a draw with the program Randomizelist.

The health agents conducted home visits with the aim of inviting those selected to participate in the research according to the inclusion and exclusion criteria, attending a meeting at the fishermen colony, where the project was explained and the consent form was read. Those who could not attend the meeting was scheduled to have a consultation with the doctor in charge, where the objectives of the research were explained in the consent form read.

Fishermen of both genders, older than 18 years of age and active in their occupation participated in the study. Individuals who did not agree to signing the consent form, those working night shifts and those under the effect of some medication used in the previous 24 hours or that had any limitation to undergo examination for blood collection were excluded. The individuals that presented some previously diagnosed condition that was associated to or that could influence the levels of vitamin D, such as malabsorption diseases, burns, liver disease, kidney disease and calcium metabolism diseases were also excluded.

A semi-structured questionnaire was applied, which contained identification data such as codified name to protect the identity, date of birth, gender, weight, height, body mass index (BMI) and time in the occupation, besides variables related to possible risk factors that interfered in the VD serum levels such as diet, supplementation of VD or calcium, sunscreen use, the presence of skin le- 
sions, phototype and index of solar exposure.

Soon after the skin was assessed with inspection and palpation, what allowed the accurate classification of the eruptive elements. The dermatologist performed dermatoscopy to evaluate pigmented skin lesions, making it possible to accurately differentiate between melanocytic and non-melanocytic pigmented lesions, and many times differentiating between benign and malignant lesions. In the cases with suspected malignant lesions, biopsy and surgery for treatment and confirmation of the diagnosis were performed. In the cases of premalignant lesions, cryotherapy was used for their treatment.

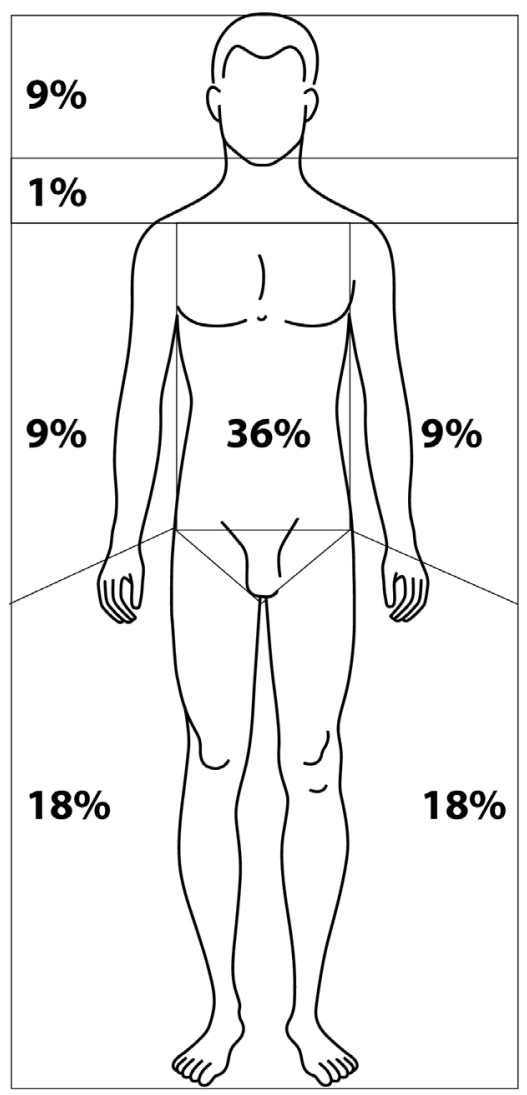

FIGURE 1: Fraction of the area exposed to the sun. Source: Barger-Lux et al, $2002 .^{18}$
The analysis of sun exposure was made from the determination of the fraction of exposed area (FEA). It is calculated by dividing the body into multiples of nine in terms of site and time of sun exposure outdoors, and time of exposure (TE) to the sun per week, in amount of hours and minutes in which the body receives sun light (Figure 1 and Table 1). The index of solar exposure (ISE) was determined by multiplying TE by FEA. ${ }^{18}$

After applying the questionnaire, serum levels of calcidiol $25(\mathrm{OH}) \mathrm{D}, \mathrm{PTH}$, calcium and phosphorus were requested. Biochemistry, calcium and phosphorus dosage were performed by calorimetry using the automated device A25 of the company Biosystems. The dosages of ionized calcium were performed by the technique of ion-selective electrode of the equipment AVL 9180. PTH dosage was performed by the technique of chemiluminescence with the automated device DXI from the company Backman; and that of $25(\mathrm{OH})$ D was performed by the technique of electrochemiluminescence with the automated device Modular E from the company Roche.

Were considered as reference levels: calcium: insufficiency $<8.5 \mathrm{mg} / \mathrm{dl}$. sufficiency 8.5 to $10.8 \mathrm{mg} / \mathrm{dl}$ and high $>10.8 \mathrm{mg} / \mathrm{dl}$; phosphorus: insufficiency $<2.5 \mathrm{mg} / \mathrm{dl}$, sufficiency 2.5 to $4.8 \mathrm{mg} / \mathrm{dl}$ and high $>4.8 \mathrm{mg} / \mathrm{dl}$; calcidiol $(25(\mathrm{OH}) \mathrm{D})$ : deficiency $<20 \mathrm{ng} / \mathrm{mL}$, insufficiency $21-29 \mathrm{ng} / \mathrm{mL}$, sufficiency $30-100 \mathrm{ng} / \mathrm{mL}$ and high $>100 \mathrm{ng} / \mathrm{mL}$; parathyroid hormone: insufficiency $<15 \mathrm{pg} / \mathrm{mL}$, sufficiency 15 to $65 \mathrm{pg} / \mathrm{mL}$ and high $>65 \mathrm{pg} / \mathrm{mL}$.

The participants presenting any abnormalities in the blood tests were referred to the dietitian of the municipality to receive education on diet and to a dermatologist for supplementation of vita$\min \mathrm{D}$.

The data obtained were expressed in percentages. The comparative analysis between the means of the groups was made with the Chi-square test. The correlations between the biochemical levels (serum levels of vitamin D, calcium, phosphorus and PTH), the time of solar exposure, the index of solar exposure and the skin lesions were established with the linear coefficient of Pearson. A significance of $5 \%(p<0.05)$ was considered. All analyses were performed using the software Genes.

\section{RESULTS}

The sample had the following characteristics: $56.1 \%$ of males and $43.9 \%$ of females with no significant difference between the classes $\left(x^{2}=1.44 ; g l=1 ; p>0.05\right) ;$ the age ranged from 40 to 50

\begin{tabular}{|c|c|c|c|c|c|c|c|c|}
\hline & \multirow{2}{*}{$\begin{array}{l}\text { Adaptation of the } \\
\text { "rule of nines" }\end{array}$} & \multicolumn{3}{|c|}{ Category 1} & \multicolumn{2}{|c|}{ Category 2} & \multicolumn{2}{|c|}{ Category 3} \\
\hline & & No shirt & Long-sleeved shirt & Short-sleeved shirt & Shorts & Pants & No hat & $\begin{array}{l}\text { With } \\
\text { hat }\end{array}$ \\
\hline 2 arms & 0.18 & 0.18 & 0.04 & 0.14 & & & & \\
\hline 2 legs & 0.36 & & & & 0.24 & 0.00 & & \\
\hline Anterior trunk & 0.18 & 0.09 & 0.00 & 0.00 & 0.00 & 0.00 & & \\
\hline Posterior trunk & 0.18 & 0.09 & 0.00 & 0.00 & 0.00 & 0.00 & & \\
\hline Head & 0.09 & & & & & & 0.07 & 0.03 \\
\hline Perineum & 0.01 & & & & & 0.00 & & \\
\hline Total & 1.00 & 0.36 & 0.04 & 0.14 & 0.24 & 0.00 & 0.07 & 0.03 \\
\hline
\end{tabular}

Source: Barger-Lux, et al, 2002. ${ }^{18}$ 
years in $35.46 \%$ of the sample; the time in the occupation was above 15 years for $54.72 \%$ of those interviewed $\left(x^{2}=50.07 ; \mathrm{gl}=3 ; \mathrm{p}<0.01\right)$; $39.18 \%$ of the volunteers were overweight $\left(x^{2}=79.69 ; g l=5 ; p<0.01\right)$ and $72.9 \%$ did not report any associated conditions $\left(x^{2}=21.6 ; \mathrm{gl}=7\right.$; $\mathrm{p}<0.01)$. Of those that had any condition, hypertension was the most common and was seen in $45 \%$ of the volunteers.

Among the food there are considered sources of VD we highlight fish and eggs. In the population studied, we observed that $31.75 \%$ ate fish three times a week $\left(x^{2}=78.67 ; g l=7 ; p<0.01\right)$ and the majority $(31.75 \%)$ did not eat eggs $\left(x^{2}=78.67 ;\right.$ gl=7; $\left.p<0.01\right)$ (Graph 1). Moreover, we also observed that almost all volunteers $(95.27 \%)$ did not take any diet supplement $\left(\mathrm{x}^{2}=81 ; \mathrm{gl}=1 ; \mathrm{p}<0.01\right)$ and $66.89 \%$ did not have the habit of drinking alcoholic drinks $\left(x^{2}=11.56 ; \mathrm{gl}=1\right.$; $0<0.01)$.
Although the occupation demanded constant sun exposure, most of those interviewed $(62.8 \%)$ did not use sunscreen; a small portion of $16.9 \%$ used it daily; and $20.3 \%$ used it occasionally $\left(x^{2}=39.44 ; g l=2 ; p<0.01\right)$. During dermatologic examination, no skin lesions were seen in $66.9 \%\left(x^{2}=11.56 ; g l=1 ; p<0.01\right)$ of the volunteers. Among those who had lesions (33.1\%), the diagnosis was divided into those who had skin cancer $(8.2 \%)$ and those with precancerous/actinic keratosis (8.2\%) and other types of skin lesions (83.6\%) $\left(x^{2}=36.89 ; g l=2 ; p<0.01\right)$. Among other types of lesions the most frequent were pityriasis versicolor $(25 \%)$ and seborrheic dermatitis (17.5\%).

Graph 2 shows the phototype distribution of the volunteers in the study: we observed that $42.56 \%$ of the volunteers had phototype III and $35.81 \%$ phototype IV $\left(x^{2}=98.8 ; g l=5 ; p<0.01\right)($ Graph 2$)$.
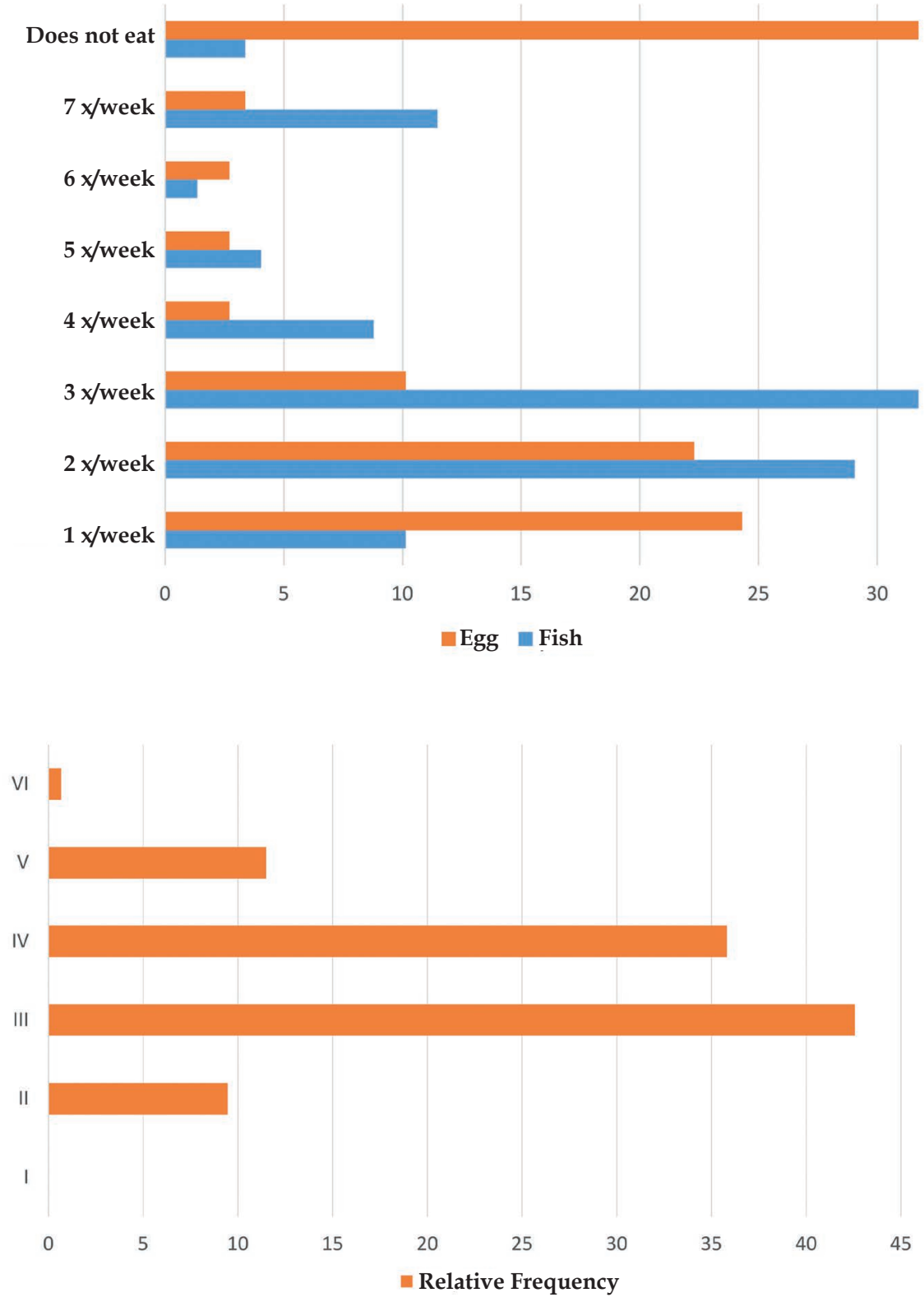

GraPH 1: Fish and egg dietary consumption 
Daily sun exposure was a constant and occurred in $91.83 \%$ of the fishermen $\left(\mathrm{x}^{2}=70.56 ; \mathrm{gl}=1 ; \mathrm{p}<0.01\right)$. The index of sun exposure most commonly found in the group $(49.65 \%)$ was that of from 0.1 to 10 $\left(\mathrm{x}^{2}=44.96 ; \mathrm{gl}=3 ; \mathrm{p}<0.01\right)$.

There was vitamin $\mathrm{D}$ deficiency in a small portion of the cases $(11.46 \%)$ with most results $(87.7 \%)$ showing levels of $25(\mathrm{OH})$ $\mathrm{D}$ above $30 \mathrm{ng} / \mathrm{mL}\left(\mathrm{x}^{2}=210.76 ; \mathrm{gl}=3 ; \mathrm{p}<0.01\right)$. The levels of calcium were normal in $98.34 \%$ and high in $1.66 \%$ of those in the study. Phosphorus and PTH were within the normal range in $100 \%$ of the cases (Graph 3).

According to the Pearson's linear correlation test, a correlation between the variables studied was not observed, except for the variables regarding the use and frequency of use of sunscreen with $\mathrm{r}=0.7 ; \mathrm{p}<0.05$ (Table 2).

\section{DISCUSSION}

The geographical location of the municipality of the study is latitude $09^{0} 59^{\prime} 08^{\prime \prime}$ and longitude $36^{0} 21^{\prime} 03^{\prime \prime}$, with a rainy tropical climate and dry summer. ${ }^{19}$ Due to these characteristics, the UVI levels are usually high. This represents very intense (UVI between 8 and 10) or extreme (UVI above 11) damage to human health. ${ }^{19}$ These levels can be seen even before $9 \mathrm{AM}$, throughout the year. ${ }^{20}$

Most fishermen in the sample ranged between 30 and 50 years in age, had phototype III and IV and were performing the occupation for over than 15 years. These data are the same found by Bezerra (2011) who, in his study with fishermen, found a mean age of $46.3 \pm 9.54$ years, ranging from 30 and 60 years. Predominance of phototype IV and mean time in the occupation of $29 \pm 10.3$ years, ranging from 12 and 45 years. ${ }^{21}$

$120,00 \%$

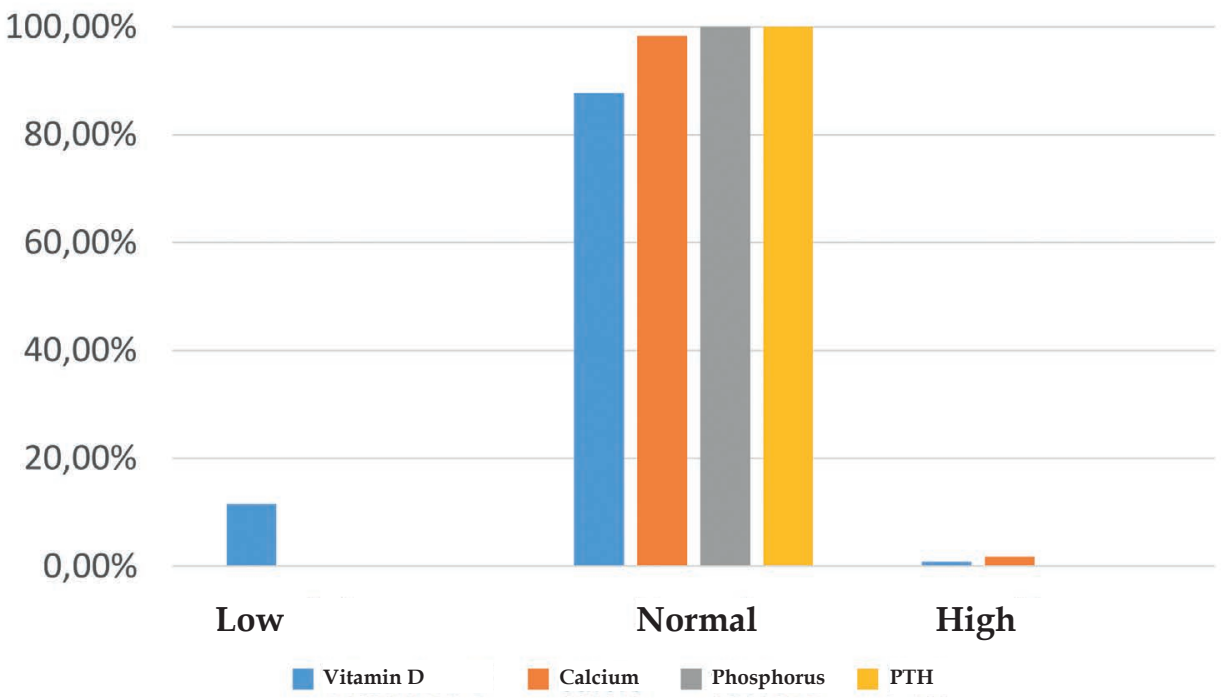

GrAPH 3: Biochemical analysis

\begin{tabular}{llllllllllll}
\hline \multicolumn{8}{c}{ TABLE 2: Estimation of the Pearson's coefficient of correlation between the variables studied } \\
\hline & TOcc & UProt & ATP & Lesion & SEI & Photot & VitD & Ca & P & PTH \\
\hline BMI & $-\mathbf{0}, 045$ & 0,145 & 0,156 & 0,197 & 0,153 & 0,155 & $-0,068$ & 0,003 & $-0,120$ & $-0,062$ \\
TOcc & - & $-0,238$ & $-0,023$ & 0,037 & $-0,090$ & $-0,129$ & 0,191 & $-0,201$ & 0,009 & 0,059 \\
UProt & - & - & $0,705^{*}$ & $-0,073$ & $-0,013$ & 0,133 & 0,001 & 0,013 & $-0,154$ & 0,033 \\
ATP & - & - & - & $-0,030$ & 0,082 & 0,071 & 0,096 & $-0,055$ & $-0,096$ & 0,001 \\
Lesion & - & - & - & - & - & 0,108 & 0,114 & 0,049 & $-0,036$ & $-0,018$ & 0,011 \\
SEI & - & - & - & - & - & 0,202 & $-0,068$ & $-0,018$ & 0,030 & $-0,218$ \\
Photot & - & - & - & - & - & - & 0,022 & $-0,075$ & $-0,029$ & $-0,230$ \\
VitD & - & - & - & - & - & - & - & 0,064 & 0,015 & 0,115 \\
Ca & - & - & - & - & - & - & - & - & - & 0,104 & 0,028 \\
P & - & - & - & - & - & - & - & - & - & $-0,117$ \\
\hline
\end{tabular}

$\mathrm{BMI}=$ body mass index; $\mathrm{TOcc}=$ time of occupation; $\mathrm{Uprot}=\mathrm{use}$ of sun protection; $\mathrm{ATP}=$ amount of time using sunscreen; lesion = skin lesion; $\mathrm{SEI}=$ solar exposure index; Photot = phototype; VitD = vitamin D; $\mathrm{Ca}=$ calcium, $\mathrm{P}=$ phosphorus, $\mathrm{PTH}=$ parathyroid hormone

*Significant at $1 \%$ by $\mathrm{T}$ test 
BMI is used in epidemiological studies as an initial approximation of tendency of obesity in populations. The most commonly found BMI and the sample was between 25.0-29.9 and 39.18\% of the volunteers, what represents excessive weight; however, in the study where the level of satisfaction with the body image was assessed, obesity and physical activity indicators in a fishermen village in Ceará, the BMI indexes shown for the total sample were $22.6 \pm$ $2.3 \mathrm{~kg} / \mathrm{m}^{2}$, revealing that the sample is within the acceptable range. ${ }^{22}$

When asked, $72.97 \%$ of those in the study had no associated diseases. Between those who had, the most common was hypertension in a frequency of $45 \%$ of the volunteers. Studies performed showed that fishermen have a high prevalence of self-reported medical conditions, high prevalence of self-medication, poor diets and frequently smoked. ${ }^{23}$ The main health complaints were related to the musculoskeletal system, respiratory diseases, digestive system and ocular diseases, besides auditory problems.

Alcohol consumption was little seen in the sample studied. We observed that $66.9 \%$ of those in the study did not drink alcoholic drinks and only $2 \%$ drank them daily. These data disagree with a study performed in 2010 in a French fishermen and sailor population where it was observed that the daily consumption of alcohol was significantly higher among fishermen than in sailors $(52.4 \mathrm{~g} /$ day, $95 \% \mathrm{CI}=49.3-55.4$ vs. $44.8 \mathrm{~g} /$ day, $95 \% \mathrm{CI}=43.0-46.6$; $\mathrm{p}=$ $0.0003) .^{24}$

Even though $91.83 \%$ of the fishermen in the study exposed daily to the sun, $62.83 \%$ of them did not use sunscreen. These data were the same found in the research conducted with beach workers, in which $85.4 \%$ frequently worked exposed to the sun but $61.3 \%$ did not use sunscreen. ${ }^{25}$

The skin lesions found among those interviewed (33.1\%) were divided into those not related to sun exposure $(83.6 \%)$ and those related to UVR (16.4\%). One article relates the prolonged exposure of fishermen and other workers under the sun in their work environment with skin conditions caused by ultraviolet radiation. ${ }^{26}$ The authors defend the need for primary prevention in those workers against the effects of ultraviolet rays, particularly in those with less pigmented skin.

The skin lesions related to UVR researched in the sample were the precancerous ones, represented by actinic keratosis, found in a frequency of $2.7 \%$, actinic cheilitis, $0 \%$ and by malignant skin tumors such as basal cell carcinoma $(2.7 \%)$ and squamous cell carcinoma $(0 \%)$. These data are partially compatible to the study, whose objective was to evaluate the role of general practitioners in selecting the population, mainly made by fishermen and farmers in the city in the north of Portugal, in which thorough skin examination by a dermatologist revealed $31 \%$ of actinic keratosis, $5 \%$ of leucoplakia, $7 \%$ of basal cell carcinoma, $8 \%$ of squamous cell carcinoma, and $1 \%$ of melanoma. ${ }^{27}$ Similar data were observed in a previous study conducted in another coastal city of northeastern Brazil where clinically no cases of actinic keratosis or cutaneous neoplasms were diagnosed in the participants of the study. ${ }^{21}$

The frequency of skin cancer in fishermen and sailors has decreased over the last years. Among the reasons for this reduction we highlight the lower number of workers in these occupations, changes in work shift (night) and the use of sunscreen. However, in Brazil, skin cancer is the most frequent and corresponds to $30 \%$ of all malignant tumors registered in the country. ${ }^{28}$ In this study, all fishermen working at night were excluded and most volunteers did not use sunscreen, therefore, not explaining the low frequency of skin cancer in the sample studied.

There are many reasons that can explain the low incidence of skin cancer in this research. Among them we highlight: age over 40 years, low phototypes and constant sun exposure.

$\mathrm{BCC}$ is the most frequent of the epithelial malignant neoplasms and represents $65 \%$ of the total. It generally occurs in individuals older than 40 years. ${ }^{29,30}$ The sample of this study was made by $35.46 \%$ of the population aged between 40 and 50 years. Of the cases diagnosed with skin cancer the sample, all had BCCs, $25 \%$ of the patients were aged between $40-50$ years, $50 \%$ between $50-60$ and $25 \%$ were older than 60 years.

SCC frequency is of around $20 \%$ of the nonmelanoma skin cancers (NMSC) and it generally occurs in more advanced ages-after 50 years. These characteristics can explain the absence of diagnosis of this type of epithelial neoplasms among those in the study, since most volunteers were younger than 50 years.

Skin cancer is caused by sun exposure and its incidence rate is higher in lighter skin, sensitive to the sun. ${ }^{31}$ Among the $2.7 \%$ of cases diagnosed with BCC, $50 \%$ had phototype III and 50\% had phototype IV. Of the individuals in the research, most were classified in the intermediate phototypes, of which $42.56 \%$ had phototype III and $35.81 \%$, phototype IV. Therefore, individuals with that skin type have a lower incidence of cancer when compared to lower phototypes, that burn more easily than tan. Maybe for this reason there was a low number of skin cancer cases in the population studied.

Daily sun exposure was constant in the study and occurred and $91.83 \%$ of the cases. The explanation for a low frequency of NMSC in the fishermen can be due to the fact that chronic sun exposure leads to skin changes, that represent a defense mechanism with increasing the number of cell layers in the epidermis between the rete ridges and also melanocytes, besides not causing cutaneous immunosuppression, differently to the acute exposure to UVR. ${ }^{21}$

Vitamin D deficiency was diagnosed in $11.47 \%$ of the patients studied. This datum is not in agreement with the literature, since vitamin D deficiency is currently a worldwide public health problem in all age groups. According to the mapping performed, there was a prevalence of $77 \%$ of VD lower than $30 \mathrm{ng} / \mathrm{mL}$ in individual studies conducted with adults in Brazil. ${ }^{32}$ In these studies, the prevalence of vitamin D deficiency $(25(\mathrm{OH}) \mathrm{D}<29 \mathrm{ng} / \mathrm{mL})$ is between $33 \%$ to $71.2 \%$ in Brazil. ${ }^{33-36}$

The population older than 60 years of age in the sample of this study was $0.7 \%$ and this characteristic could have contributed to a low frequency of vitamin D deficiency, since the elderly are more prone to developing this deficiency because they expose less to UVR, have a reduced ability of cutaneous production, have inadequate diets and use many medications that can interfere with VD metabolism. ${ }^{37,38}$

BMI is another datum that could have contributed to the low frequency of vitamin D deficiency among those studied, because only $2.7 \%$ were classified as morbidly obese and lower levels of serum $25(\mathrm{OH}) \mathrm{D}$ can be seen in the morbidly obese patients secondary 
to a disturbance in tissue distribution, resulting from increased fat mass. It was demonstrated that the percentage of body fat is inversely related to serum levels of $25(\mathrm{OH}) \mathrm{D}$ in healthy women. ${ }^{39}$

Although the levels of VD were normal, the data in the present study show that they were not influenced by the dietary habits of the fishermen in the research since $31.75 \%$ of them did not eat eggs, only $31.75 \%$ ate fish (three times a week) and $95.27 \%$ were not taking supplements. VD can be obtained through food such as codfish liver oil, oily fish and eggs. However, these sources are scarce and humans depend mainly on the cutaneous production catalyzed by the UVB rays from the sun.

Sunlight is the most important source for VD because it stimulates the production of vitamin D3 in the skin and is dependent of, besides the factors already mentioned, the skin pigmentation, the clothing style and the use of sunscreen. ${ }^{40}$ Since the fishermen were exposed to the sun daily in $91.83 \%$ of the cases, working on average 21 to 28 hours per week and $32.19 \%$ of the time, this enables that $87.7 \%$ of those in the study have vitamin levels above $30 \mathrm{ng} / \mathrm{mL}$.

Other characteristics of the participants in this study, such as a low number $(0.7 \%)$ of dark-skinned population (phototype IV) and the absence of the habit of using sunscreen and most of those researched $(62.83 \%)$, could maybe have contributed to the low frequency of cases of vitamin D deficiency, since dark-skinned people have more difficulty with the transformation of 7-dehydrocholesterol into vitamin $\mathrm{D}$, the serum concentration of $25(\mathrm{OH}) \mathrm{D}$ is lower and vitamin $\mathrm{D}$ deficiency is more common in patients using photoprotection. ${ }^{41,42}$

Serum levels of phosphorus, calcium and other factors can increase or reduce the renal production of $1.25(\mathrm{OH}) \mathrm{D}$. The $1,25(\mathrm{OH}) \mathrm{D}$ regulates its own synthesis and decreases the synthesis and secretion of PTH in parathyroid glands. Since most of the individuals had VD levels considered satisfactory by most authors, the finding of $100 \%$ of normal dosage of phosphorus and PTH and $98.34 \%$ of normal dosage of calcium was expected.

This high prevalence of elevated levels of vitamin D could have been responsible for the low incidence of NMSC in the fisher- men once individuals with levels of $25(\mathrm{OH}) \mathrm{D}$ of $32 \mathrm{ng} / \mathrm{mL}$ seem to have a $40 \%$ lower risk of developing NMSC and, possibly, higher levels of $25(\mathrm{OH}) \mathrm{D}$ can be a protective factor for the development of skin cancers. ${ }^{43}$

Both the production of vitamin D and its implementation has demonstrated protective effects through mechanism involving the receptor vitamin D in many diseases and types of cancer, including skin cancer. ${ }^{44}$

VD produced in the skin can suppress the formation of epidermal tumors through VDR, binding $1.25(\mathrm{OH}) \mathrm{D}$ through the modulation of the activation or suppression of genes involved in the signaling of the processes that stop the cycle in G0/G1. This occurs via the inhibition of proliferation and stimulation of differentiation, immune regulation, and stimulation of DNA damage repair. Low levels of $1.25(\mathrm{OH}) \mathrm{D}$ could lead to the deregulation of these processes, promoting cell proliferation and inhibiting apoptosis. ${ }^{45-47}$

Besides, the vitamin D endogenously produced after exposure to UVB rays can have protective, antitumor, and photo adaptive activities against exposure to solar radiation after the initial exposure. $^{48}$

\section{CONCLUSION}

There was a low prevalence of diagnosed cases of skin cancer among the fishermen when compared to the general population. In the cases diagnosed with skin cancer, the values found of SEI were higher than 10. A satisfactory rate of vitamin D, calcium, phosphorus, and parathyroid hormone was observed in the study population.

The study did not show a statistically proven relationship between sun exposure, vitamin D levels and clinical skin changes caused by solar exposure.

The fact that fishermen expose chronically to the sun, working for over 50 years exposed to the sun between 21 and 28 hours per week with no photoprotection contributed to a low frequency of vitamin D deficiency.

High levels of vitamin D could have been a protective factor against the development of skin cancer.]

\section{REFERENCES}

1. Sliney DH. Radiometric quantities and units used in photobiology and photochemistry: recommendations of the commission internationale de l'Eclairage (International Commission on Illumination). Photochem Photobiol. 2007;83:425-32.

2. Who.in [Internet]. World Health Organization; ICO Information Centre on Human Papiloma Virus (HPV) and Cervical Cancer. Human papillomavirus and related cancers in Brazil. Summary Report, 2014 [cited 2016 Dec 05]. Available from: www.who.int/hpvcentre.

3. Weller RB. The health benefits of UV radiation exposure through vitamin D production or non-vitamin D pathways. Blood pressure and cardiovascular disease. Photochem Photobiol Sci. 2017;16:374-80.

4. Holick MF, Binkley NC, Bischoff-Ferrari HA, Gordon CM, Hanley DA, Heaney RP, et al. Evaluation, treatment, and prevention of vitamin $D$ deficiency: an Endocrine Society clinical practice guideline. J Clin Endocrinol Metab. 2011;96:1911-30.
5. Castro LCG. 0 sistema endocrinológico vitamina D. Arq Bras Endocrinol Metab. 2011;55:566-75.

6. Maeda SS, et al. Recomendações da Sociedade Brasileira de Endocrinologia e Metabologia (SBEM) para o diagnóstico e tratamento da hipovitaminose D. Arq Bras Endocrinol Metab. 2014;58:411-33.

7. Atef SH. Vitamin D assays in clinical laboratory: past, present and future challenges. J Steroid Biochem Mol Biol. 2018;175:136-7.

8. Silva BCC, Camargos BN, Fujii JB, Dias EP, Soares MMS. Prevalência de deficiência e insuficiência de vitamina D e sua correlação com PTH, marcadores de remodelação óssea e densidade mineral óssea, em pacientes ambulatoriais. Arq Bras Endrocrinol Metab. 2008;52:482-8.

9. Sbd.org.br [Internet]. Consenso Brasileiro de Fotoproteção. Recomendações da Sociedade Brasileira de Dermatologia [cited 2016 Dec 05]. Available from: http:// www.sbd.org.br/publicacao/consenso-brasileiro-de-fotoprotecao/. 
10. Schmitt JV, Miot HA. Actinic keratosis: a clinical and epidemiological revision. An Bras Dermatol. 2012;87:425-34.

11. Kopke LFF, Batista JN, Gouvêa PS. Basal cell carcinoma mimicking intranasa tumor: treatment by Munich method of micrographic surgery. An Bras Dermatol. 2007;82:543-7.

12. Reichrath J. Skin cancer prevention and UV-protection: How to avoid vitamin D-deficiency? Br J Dermatol. 2009:161:54-60.

13. Fitzpatrick TB. The validity and practicality of sun-reactive skin types I through VI. Arch Dermatol. 1988:124:869-71.

14. Kannan S, Lim HW. Photoprotection and vitamin D: a review. Photodermatol Photoimmunol Photomed. 2014;30:137-45

15. Byrne SN. How much sunlight is enough? Photochem Photobiol Sci. 2014;13:84052.

16. Ima.al.gov.br [Internet]. Instituto de Meio Ambiente. Semana da água será encerrada com jogos educativos em Jequiá da Praia [cited 2016 Dec 05]. Available from: http://ima.al.gov.br/semana-da-agua-encerra-com-jogoseducativos-em-jequia-da-praia/

17. Ceballos AGC, Santos SL, Silva ACA, Pedrosa BRF, Câmara MMA, Silva SL. Exposição solar ocupacional e câncer de pele não melanoma: estudo de revisão integrativa. Revista Brasileira de Cancerologia 2014:60:251-8.

18. Barger-Lux MJ, Heaney RP. Effects of above average summer sun exposure on serum 25-hydroxyvitamin D and calcium absorption. J Clin Endocrinol Metab. 2002;87:4952-6

19. Ibge.gov.br [Internet]. Instituto Brasileiro de Geografia e Estatística. Saúde [cited 2016 Dec 05]. Available from: http://ibge.gov.br/cidadesat/painel/historico.php ?codmun $=270375 \&$ search $=$ alagoas\% 7 Cjequia-da-praia\%7Cinphographics:history\&lang $=$ ES.

20. Corrêa MP. Solar ultraviolet radiation: properties, characteristics and amounts observed in Brazil and South America. An Bras Dermatol. 2015;90:297-313.

21. Bezerra SMFMC, Sotto MN, Orii NM, Alves C, Duarte AJS. Effects of long-term chronic exposure to sun radiation in immunological system of commercial fishermen in Recife, Brazil. An Bras Dermatol. 2011;86:222-33.

22. Coccetrone R, Couto PG, Oliveira FR. Nível de satisfação da imagem corporal, indicadores de obesidade e atividade física em uma vila de pescadores do Ceará. Rev. Acta Brasileira do Movimento Humano. 2011;1:14-22.

23. Novalbos J, Nogueroles P, Soriguer M, Piniella F. Occupational health in the Andalusian Fisheries Sector. Occup Med (Lond). 2008;58:141-3.

24. Fort E, Massardier-Pilonchéry A, Bergeret A. Psychoactive substances consumption in French fishermen and merchant seamen. Int Arch Occup Environ Health. 2010:83:497-509.

25. Lucena EES, Costa DCB, Silveira EJD, Lima KC. Prevalência de lesões labiais em trabalhadores de praia e fatores associados. Revista de Saúde Pública. 2012;46:1051-7.

26. Gruber F, Peharda V, Kastelan M, Brajac I. Occupational skin diseases caused by UV radiation. Acta Dermatovenerol Croat. 2007:15:191-8.

27. Duarte AF, da Costa-Pereira A, Del-Marmol V, Correia 0. Are general physicians prepared for struggling skin cancer? Cross-sectional study. J Cancer Educ. 2018;33:321-4.

28. Inca.gov.br [Internet]. Instituto Nacional de Câncer José Alencar Gomes da Silva. Coordenação de Prevenção e Vigilância. Estimativa 2016: incidência do câncer no Brasil. 2016. Rio de Janeiro: INCA; 2015 [cited 2016 Dec 05]. Available from: http:// www.inca.gov.br/bvscontrolecancer/publicacoes/edicao/Estimativa_2016.pdf.
29. Sampaio SAP, Rivitti EA. Dermatologia. 3rd.ed. São Paulo: Artes Médicas; 2007.

30. Leiter U, Garbe C. Epidemiology of Melanoma and Nonmelanoma Skin Cancer The Role of Sunlight. Adv Exp Med Biol. 2008;624:89-103.

31. Armstrong BK, Kricker A. The epidemiology of UV induced skin cancer. $J$ Photochem Photobiol B. 2001;63:8-18.

32. Palacios C, Gonzalez L. Is vitamin D deficiency a major global public health problem? J Steroid Biochem Mol Biol. 2014;144 Pt A:138-45.

33. Saraiva GL, Cendoroglo MS, Ramos LM, Araújo LMQ, Vieira JGH, Maesa SS, et al. Prevalência da deficiência, insuficiência de vitamina $\mathrm{D}$ e hiperparatiroidismo secundário em idosos institucionalizados e moradores na comunidade da cidade de São Paulo, Brasil. Arq Bras Endocrinol Metab. 2007:51:437-42.

34. Russo LAT, Gregório LH, Lacativa PGS, Marinheiro LPF. Concentração plasmática de 25 hidroxivitamina $D$ em mulheres na pós-menopausa com baixa densidade mineral óssea. Arq Bras Endocrinol Metab. 2009;53:1079-87.

35. Cabral MA, Borges CN, Maia JM, Aires CA, Bandeira F. Prevalence of vitamin D deficiency during the summer and its relationship with sun exposure and skin phototype in elderly men living in the tropics. Clin Interv Aging. 2013;8:1347-51.

36. Neves JPR, Silva AS, Morais LCSL, Diniz AS, Costa MJC, Asciutti LSR, et al. Concentrações de 25-hidroxivitamina $D$ e níveis pressóricos em idosos hipertensos. Arq Bras Endocrinol Metab. 2012;56:415-22.

37. Bandeira F, Griz L, Freese E, Lima DC, Thé AC, Diniz ET, et al. Vitamin D deficiency and its relationship with bone mineral density among postmenopausal women living in the tropics. Arq Bras Endocrinol Metabol. 2010;54:227-32.

38. Premaor MO, Furlanetto TW. Hipovitaminose D em adultos: entendendo melhor a apresentação de uma velha doença. Arq Bras Endocrinol Metab. 2006;50:25-37.

39. Arunabh S, Pollack S, Yeh J, Aloia JF. Body fat content and 25-hydroxyvitamin d levels in healthy women. J Clin Endocrinol Metab. 2003:88:157-61.

40. Lips P, van Schoor NM, de Jongh RT. Diet, sun, and lifestyle as determinants of vitamin D status. Ann N Y Acad Sci. 2014;1317:92-8.

41. Libon F, Cavalier E, Nikkels AF. Skin color is relevant to vitamin D synthesis. Dermatology. 2013;227:250-4.

42. Bogaczewicz J, Karczmarewicz E, Pludowski P, Zabek J, Wozniacka A. Requirement for vitamin $D$ supplementation in patients using photoprotection: variations in vitamin D levels and bone formation markers. Int J Dermatol. 2016;55:e176-83.

43. Tang JY, Parimi N, Wu A, Boscardin WJ, Shikany JM, Chren MM, et al. Inverse association between serum $25(\mathrm{OH})$ vitamin $\mathrm{D}$ levels and non-melanoma skin cancer in elderly men. Cancer Causes Control. 2010;21:387-91.

44. Burns EM, Elmets CA, Yusuf N. Vitamin D and skin cancer. Photochem Photobiol. 2015;91:201-9

45. Bikle DD. Protective actions of vitamin D in UVB induced skin cancer. Photochem Photobiol Sci. 2012;11:1808-16

46. Deeb KK, Trump DL, Johnson CS. Vitamin D signalling pathways in cancer: potential for anticancer therapeutics. Nat Rev Cancer. 2007;7:684-700.

47. Zeljic K, Supic G, Magic Z. New insights into vitamin D anticancer properties: focus on miRNA modulation. Mol Genet Genomics. 2017:292:511-24.

48. Moukayed M, Grant WB. The roles of UVB and vitamin D in reducing risk of cancer incidence and mortality: A review of the epidemiology, clinical trials, and mechanisms. Rev Endocr Metab Disord. 2017;18:167-82.

\section{AUTHORS'CONTRIBUTIONS}

Roberta Cavalcanti Soriano Coutinho (iD) ORCID 0000-0003-3140-7340

Conception and planning of the study; Elaboration and writing of the manuscript; Obtaining, analyzing and interpreting the data; Intellectual participation in propaedeutic and/or therapeutic conduct of the cases studied; Critical review of the literature; Critical review of the manuscript

Aldenir Feitosa dos Santos $\quad$ (iD) ORCID 0000-0001-6049-9446

Approval of the final version of the manuscript; Conception and planning of the study; Elaboration and writing of the manuscript; Obtaining, analyzing and interpreting the data; Effective participation in research orientation; Critical review of the literature; Critical review of the manuscrip

João Gomes da Costa $\quad$ (iD) ORCID 0000-0002-0761-0755

Statistical analysis; Approval of the final version of the manuscript

Aleska Dias Vanderlei $\quad$ (iD) ORCID 0000-0003-4590-5025

Approval of the final version of the manuscript; Conception and planning of the study; Elaboration and writing of the manuscript; Obtaining, analyzing and interpreting the data; Effective participation in research orientation; Intellectual participation in propaedeutic and/or therapeutic conduct of the cases studied; Critical review of the literature; Critical review of the manuscript

How to cite this article: Coutinho RCS, Santos AF, Costa JG, Vanderlei AD. Sun exposure, skin lesions and vitamin D production: evaluation in a population of fishermen. An Bras Dermatol. 2019;94(3):279-86. 